\title{
IMPLEMENTASI FRAMEWORK LARAVEL UNTUK E-VOTING PEMILIHAN KETUA OSIS PADA SMK CIKINI BERBASIS WEB
}

\author{
Muhammad Farhan ${ }^{1)}$, Asri Wahyuni ${ }^{2)}$ \\ ${ }^{1}$ Program Studi Teknik Informatika, STMIK Nusa Mandiri \\ Jl. Kamal Raya No. 18, RT.1/RW.6, Ring Road Barat, Cengkareng Barat, Cengkareng, RT.6/RW.3, Cengkareng Bar., \\ Kecamatan Cengkareng, Kota Jakarta Barat, Daerah Khusus Ibukota Jakarta 11730 \\ ${ }^{2}$ Program Studi Sistem Informasi, STMIK Nusa Mandiri \\ Jl. Kamal Raya No. 18, RT.1/RW.6, Ring Road Barat, Cengkareng Barat, Cengkareng, RT.6/RW.3, Cengkareng Bar., \\ Kecamatan Cengkareng, Kota Jakarta Barat, Daerah Khusus Ibukota Jakarta 11730 \\ Email: farhan342651@gmail.com ${ }^{1}$, asri.awx @ nusamandiri.ac.id ${ }^{2}$
}

Article history

Received May 15, 2020 Revised May 20, 2019

Accepted May 28, 2019 Available online May 31, 2020

Keywords

E-voting,

Framework,

Laravel,

School

Riwayat

Diterima 15 Mei 2020

Revisi 20 Mei 2020

Disetujui 28 Mei 2020

Terbit 31 Mei 2020

Kata Kunci

E-voting,

Framework,

Laravel,

OSIS,

Sekolah

\section{Abstract}

Voting is an activity to determine opinions through the most votes. However, there are still many OSIS (Intra School Student Organizations) organizations that carry out the process of collecting non-computerized voice data specifically for the selection of new Chairwoman candidates. The selection process that is still carried out in this way causes several problems and constraints, including the processing of administrative data which takes a lot of time, the resulting information is still inaccurate because errors often occur and the level of difficulty is quite high. This is also the case with OSIS (Intra School Student Organization) Cikini Vocational School. At present the process of selecting the candidates for OSIS (Intra-School Student Organization) Chairperson at the school is still using manual or non-computerized methods. The method used for the current election is by voting through each class. As a result of these many obstacles faced by the management of OSIS (Intra School Student Organization) Cikini Vocational High School in voting matters such as processing incoming votes, the total number of votes collected from each class that takes a long time and often found inconsistent data because still using manualization. This is where the need for E-Voting arises. E-Voting is a website that can help in terms of voting for prospective Chairperson of Student Council (Intra School Student Organization) Cikini Vocational School that can process incoming votes, total votes and display the results of voting in real time.

\footnotetext{
Abstrak

Voting adalah suatu kegiatan untuk menentukan pendapat melalui suara terbanyak. Namun demikian, masih banyak organisasi OSIS (Organisasi Siswa Intra Sekolah) yang melakukan proses pengambilan data suara secara non-komputerisasi khusus nya pada pemilihan calon Ketua baru. Proses pemilihan yang masih dilakukan dengan cara tersebut menyebabkan beberapa permasalahan dan kendala, diantaranya yaitu pengolahan data administrasi yang memakan banyak waktu, informasi yang dihasilkan masih kurang akurat karena sering terjadi kesalahan dan tingkat kesulitannya cukup tinggi. Demikian halnya yang terjadi pada OSIS (Organisasi Siswa Intra Sekolah) SMK Cikini. Saat ini proses pemilihan calon ketua OSIS (Organisasi Siswa Intra Sekolah) di sekolah tersebut masih menggunakan cara manual atau nonkomputerisasi. Cara yang digunakan untuk pemilihan saat ini adalah dengan cara pencoblosan melalui tiap-tiap kelas. Akibat dari hal tersebut banyak kendala yang dihadapi oleh pengurus OSIS (Organisasi Siswa Intra Sekolah) SMK Cikini dalam urusan voting seperti pengolahan suara yang masuk, jumlah total suara pengumpulan surat suara dari tiap kelas yang memakan waktu cukup lama dan sering ditemukan data yang tidak konsisten karena masih menggunakan manualisasi. Disinilah muncul kebutuhan akan E-Voting. E-Voting merupakan suatu web yang dapat membantu dalam hal pemungutan suara untuk calon Ketua OSIS (Organisasi Siswa Intra Sekolah) SMK Cikini yang dapat memproses suara masuk, jumlah total suara dan menampilkan hasil dari pemungutan suara secara real time.
} 


\section{PENDAHULUAN}

Perkembangan teknologi saat ini mengalami kemajuan yang sangat pesat, ditandai dengan bertambah canggih dan kompleksnya penggunaan teknologi pada kehidupan sehari hari, seiring dengan hal tersebut manusia sebagai pemakai teknologi terus menerus memperbaiki dan memperbaharui aktivitas manusia itu sendiri, agar setiap tindakan maupun kegiatan dapat berjalan dengan efektif dan efisien.

OSIS (Organisasi Siswa Intra Sekolah) merupakan wadah berkumpul nya para siswa untuk mencapai tujuan tertentu. Organisasi ini terdiri dari susunan kepanitian yang terdiri dari ketua, wakil ketua, sekretaris, bendahara, kemudian seksi-seksi lainnya. Setiap jabatan di dalam OSIS (Organisasi Siswa Intra Sekolah) memiliki tugas masing-masing. Kepengurusan OSIS (Organisasi Siswa Intra Sekolah) memiliki masa kerja yang terbatas yaitu selama satu tahun dan akan diperbaharui lagi. Dalam satu tahun pendataan salah satu hal yang mempengaruhi jika diperlukan suatu saat.

Demikian halnya yang terjadi pada OSIS (Organisasi Siswa Intra Sekolah) SMK Perguruan Cikini. Saat ini proses pemilihan calon ketua OSIS (Organisasi Siswa Intra Sekolah) di sekolah tersebut masih menggunakan cara manual atau nonkomputerisasi. Cara yang digunakan untuk pemilihan saat ini adalah dengan cara pencoblosan melalui tiap-tiap kelas. Akibat dari hal tersebut banyak kendala yang dihadapi oleh pengurus OSIS (Organisasi Siswa Intra Sekolah) SMK Perguruan Cikini dalam urusan voting seperti pengolahan suara yang masuk, jumlah total suara pengumpulan surat suara dari tiap kelas yang memakan waktu cukup lama dan sering ditemukan data yang tidak konsisten karena masih manualisasi. Selain itu, penyajian hasil akhir nya masih kurang cepat, tepat dan akurat karena media penyampaian informasi saat ini hanya mading. Disinilah muncul kebutuhan akan E-Voting. E-Voting merupakan suatu web yang dapat membantu dalam hal pemungutan suara untuk calon Ketua OSIS (Organisasi Siswa Intra Sekolah) SMK Perguruan Cikini yang dapat memproses suara masuk, jumlah total suara dan menampilkan hasil dari pemungutan suara secara real time. Perancangan web E-Voting ini mencakup visi-misi Calon Ketua OSIS (Organisasi Siswa Intra Sekolah) SMK Perguruan Cikini, menghitung suara masuk dan mengkelompokkan suara masuk sesuai dengan apa yang user atau siswa pilih yang terintegrasi dalam sebuah database.

Permasalah yang berkaitan dengan E-Voting SMK Perguruan Cikini :Belum adanya media untuk melaksanakan E-voting dan masih menggunakan metode manual yaitu menggunakan media kertas. Akibat dari metode seperti itu maka sering kali saat pemilihan terjadi kesalahan dan memakan waktu yang cukup lama dan metode manualisasi tersebut, sering terdapat data yang tidak konsisten seperti hilang nya surat suara yang sudah di coblos ataupun kekeliruan terhadap surat suara apakah sah atau tidak.

\section{TINJAUAN PUSTAKA}

\section{Konsep Dasar E-Voting}

Menurut (Choer Yusfar Ilhaqul, n.d.) $E$ Voting adalah suatu metode pemungutan suara dan penghitungan suara dalam pemilihan umum dengan menggunakan perangkat elektronik. Sistem E-voting hasilnya akurat tentu akan membuat setiap orang berpikir ulang jika ingin mengajukan gugatan ke Mahkamah Konstitusi (MK). Bahkan jika dalam proses pelaksanaan $E$ voting ada indikasi kecurangan, maka proses penanganannya juga akan lebih cepat, mudah dan transparan.

\section{Model Pengembangan Sistem}

Menurut (Sasmito, 2017) Metode Waterfall merupakan model pengembangan sistem informasi yang sistematik dan sekuensial. Metode Waterfall memiliki tahapan-tahapan sebagai berikut:

- Requirements analysis and definition

Layanan sistem, kendala, dan tujuan ditetapkan oleh hasil konsultasi dengan pengguna yang kemudian didefinisikan secara rinci dan berfungsi sebagai spesifikasi sistem.

- System and software design

Tahapan perancangan sistem mengalokasikan kebutuhan-kebutuhan 
sistem baik perangkat keras maupun perangkat lunak dengan membentuk arsitektur sistem secara keseluruhan. Perancangan perangkat lunak melibatkan identifikasi dan penggambaran abstraksi sistem dasar perangkat lunak dan hubungannya.

- Implementation and unit testing

Pada tahap ini, perancangan perangkat lunak direalisasikan sebagai serangkaian program atau unit program. Pengujian melibatkan verifikasi bahwa setiap unit memenuhi spesifikasinya.

- Integration and system testing

Unit-unit individu program atau program digabung dan diuji sebagai sebuah sistem lengkap untuk memastikan apakah sesuai dengan kebutuhan perangkat lunak atau tidak. Setelah pengujian, perangkat lunak dapat dikirimkan ke customer.

- Operation and maintenance

Biasanya (walaupun tidak selalu), tahapan ini merupakan tahapan yang paling panjang. Sistem dipasang dan digunakan secara nyata. Maintenance melibatkan pembetulan kesalahan yang tidak ditemukan pada tahapan-tahapan sebelumnya, meningkatkan implementasi dari unit sistem, dan meningkatkan layanan sistem sebagai kebutuhan baru.

\section{Sistem}

Sistem adalah suatu kumpulan atau himpunan dari unsur, komponen atau variabel yang terorganisasi, saling berinteraksi, saling tergantung satu sama lain dan terpadu. (Permana, 2016).

\section{Unified Modeling Language}

Menurut (Wira, Putra, \& Andriani, 2019) UML (Unified Modeling Language) adalah salah satu standar bahasa yang banyak digunakan di dunia industri untuk mendefinisikan requirement, membuat analisis dan desain, serta menggambarkan arsitektur dalam pemrograman berorientasi objek.

\section{- Use Case Diagram}

Use case diagram merupakan pemodelan untuk kelakuan sistem informasi yang akan dibuat. Use case bekerja dengan mendeskripsikan tipikal interaksi antara user sebuah sistem dengan sistemnnya sendiri melalui sebuah cerita bagaimana sistem itu dipakai.

\section{- Activity Diagram}

Activity diagram merupakan diagram yang menggambarkkan workflow atau aktivitas dari sebuah sistem yang ada pada perangkat lunak.

\section{- Sequence Diagram}

Sequence diagram menggambarkan kelakuan objek pada use case dengan mendeskripsikan waktu hidup objek dan pesan yang dikirimkan dan diterima antar objek.

- Deployment Diagram

- Component Diagram

Component diagram menggambarkan struktur dan hubungan antar komponen piranti lunak termasuk ketergantungan (dependency).

\section{Penelitian Terkait}

Menurut (Zaen Mohammad Tufan Asri, 2018) Proses pemilihan ketua OSIS MA Nurul Ihsan NW Tilawah, sistem yang dilakukan semuanya masih konvensional, semua proses dilakukan secara manual dan hal ini dirasa kurang efektif dan efisien. Aplikasi Voting/Electronic Voting (E-Voting) dianggap lebih efektif dan lebih efisien karena semua proses secara terkomputerisasi, memberikan kemudahan bagi pengguna untuk memilih calon, mempermudah dalam proses penghitungan suara dan hasil pemilihan bisa langsung diketahui secara cepat dan akurat.

Menurut (Ridwan \& Arifin, 2016) kepercayaan masyarakat terhadap $e$ - voting masih rendah. Hal ini disebabkan akan ketakutan masyarakat akan manipulasi hasil perolehan setiap kandidat. Untuk itu perlu dibuat sebuah sistem yang dapat menjamin akurasi hasil $e$ voting, integritas data ketika melakukan pengiriman hasil voting dari pemilih ke sistem, dan memvalidasi pemilih yang sesungguhnya dalam penerimaan hasil voting. 


\section{METODOLOGI PENELITIAN}

Dalam rangka pengumpulan data yang diperlukan dalam penulisan laporan ini penulis menggunakan beberapa metode, diantaranya adalah:

\section{Teknik Pengumpulan Data}

- Observasi

Observasi ini dilaksanakan di SMK Perguruan Cikini Jakarta Utara yang beralamatkan di Jalan. Alur Laut Blok NN No.1 RT. 05 / RW.10 Rawabadak Utara, Koja, Jakarta Utara, 14230.

\section{- Wawancara}

Peneliti melakukan tanya jawab secara langsung kepada Bapak Andy Gunawan S.pd selaku Guru dan staf disekolah tersebut.

\section{- Studi Pustaka}

Pengumpulan data dari buku, materi dari perkuliahan serta yang berhubungan dengan penelitian.

\section{Model Pengembangan Sistem}

Model yang digunakan untuk pembuatan program aplikasi akademik berbasis web ini yaitu menggunakan framework Laravel. Adapun tahapan-tahapannya adalah sebagai berikut :

\section{- Analisa Kebutuhan}

Peneliti menganalisa sistem yang ada di SMK Perguruan Cikini untuk memahami masalah dan menentukan persyaratan fungsional dari sistem yang baru. Dalam hai ini, Peneliti melakukan studi analisa yang terkait dan menganalisa sistem yang ada sebagai bahan pengembangan sistem yang akan diolah ke dalam program.

\section{- Desain}

Proses perancangan sistem yang akan diimplementasikan ke dalam program, baik basis data yang dibuat dan design interface yang akan digambarkan oleh ERD dan UML. Dari hasil pengembangan analisis, kemudian membuat sebuah rancangan program sebagai media pendukung tercapainya rancangan sistem yang baru.

\section{- Code Generation}

Pada tahapan ini hasil dari fase-fase sebelumnya dituangkan kedalam kode-kode dengan memasukan hasil desain ke dalam bahasa pemrograman komputer yang telah ditentukan dalam tahap sebelumnya, dalam hal ini penulis menggunakan bahasa pemrograman PHP.

\section{- Testing}

Pengujian program dilakukan dengan menggunakan blackbox testing guna untuk mengetahui kebenaran dari pembuatan program ini secara manual, untuk mendeteksi apakah sudah benar atau belum, sudah sesuai atau belum diuji, sehingga dapat dilakukan perbaikan terlebih dahulu jika menemukan kendala.

- Support

Setelah dibuat menjadi program aplikasi maka perlu kita ketahui spesifikasi hardware dan software untuk mensupport kinerja dari website tersebut.

\section{HASIL DAN PEMBAHASAN}

\section{- Proses Bisnis Sistem}

Pengambilan suara pada pemilihan ketua dan wakil OSIS SMK Perguruan Cikini dilakukan oleh seluruh siswa/i SMK Perguruan Cikini. Proses pengambilan suara pada umumnya hampir sama seperti pemilihan umum lain nya. Siswa akan datang ke ruangan yang telah disediakan oleh pihak panitia atau OSIS. Setelah itu pihak OSIS akan memeriksa identitas si siswa melalui Kartu Pelajar dan memeriksa NIS yang tertera di kartu tersebut. Setelah di verifikasi oleh panitia maka siswa akan diberikan surat suara dan diarahkan ke bilik pencoblosan. Setelah memilih siswa akan memasukkan surat suara yang sudah tercoblos kedalam kotak suara yang mana nanti setelah acara selesai akan dibuka dan dihitung perolehan sura masing-masing pasangan calon. 


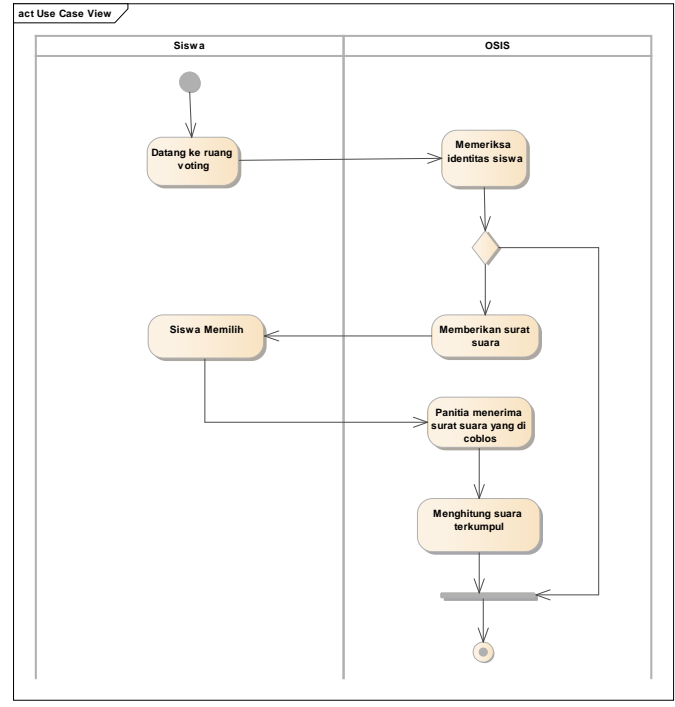

Gambar 1. Activity Diagram Prosedur Pemilihan ketua dan wakil OSIS SMK Perguruan Cikini

- Analisa Kebutuhan Software Program voting pada pemilihan OSIS (Organisasi Siswa Intra Sekolah) SMK Perguruan Cikini sudah terkomputerisasi agar lebih efisien dengan menggunakan user. Pada saat masuk ke website e-voting ini yang akan muncul pertama kali adalah form login, disini penulis hanya membuat 1 form login untuk admin dan user yang di bedakan melalui role user pada database. Berikut ini spesifikasi pengguna dari program E-voting tersebut.

Akses admin:

A1. Admin dapat melakukan Login

A2.Admin dapat menambah dan menghapus user

A3. Admin dapat menambah dan menghapus kegiatan pemilihan

A4. Admin dapat menambah dan menghapus data pasangan calon

A5. Admin dapat melakukan Logout

Akses User / Siswa:

B1. User dapat melakukan Login

B2. User dapat melakukan Voting

B3. User dapat melakukan Logout

- Desain

1. Use Case Diagram

a. Use Case Diagram Admin

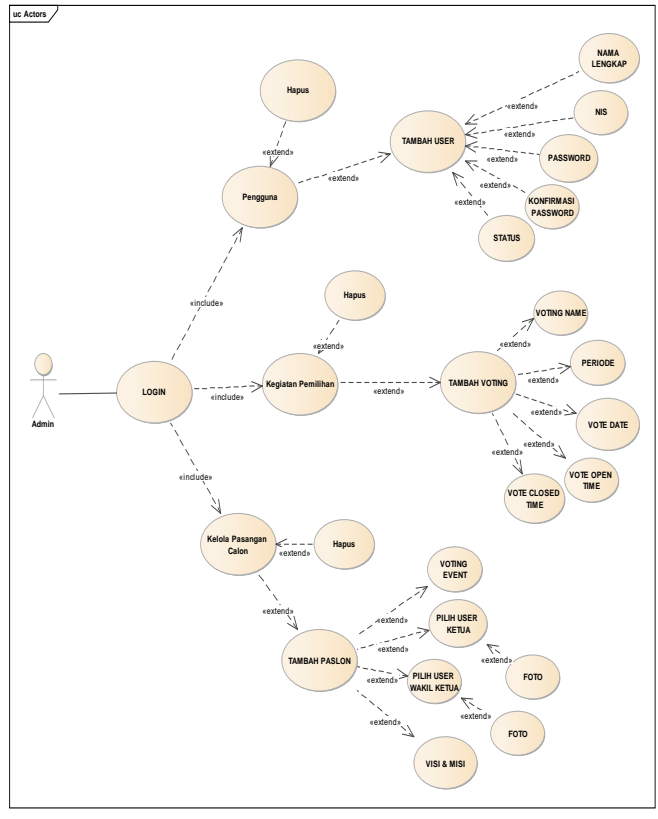

Gambar 2. Use Case Diagram Admin

b. Use Case Diagram Siswa

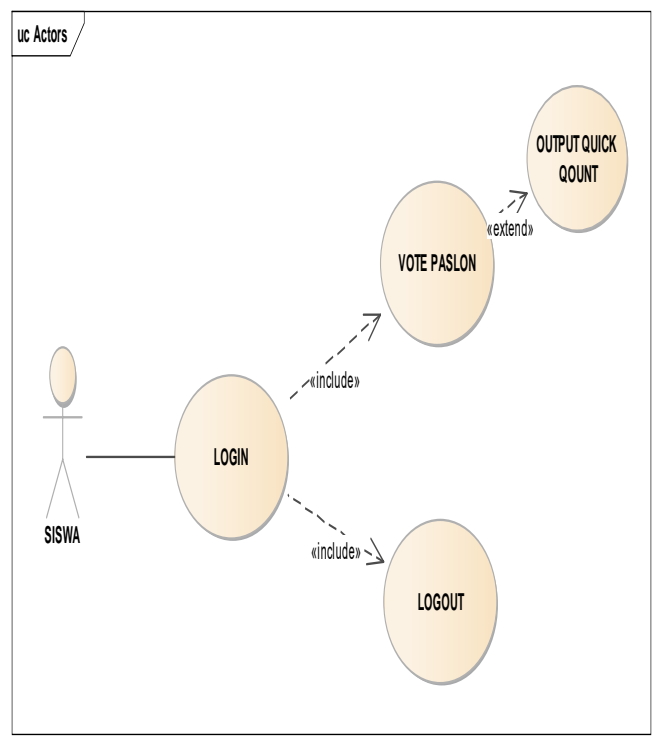

Gambar 3. Use Case Diagram Siswa 
2. Activity Diagram

a. Activity Diagram Admin

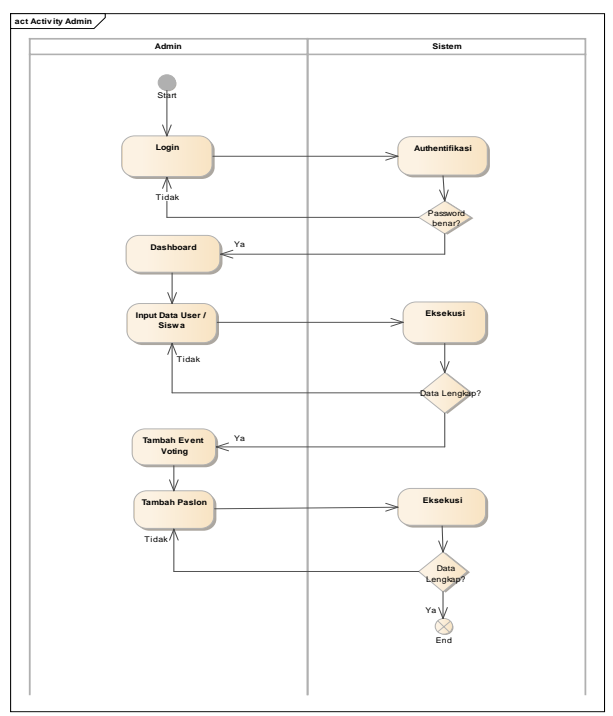

Gambar 4 Activity Diagram Admin

3. Sequence Diagram

a. Sequence Diagram Tambah User

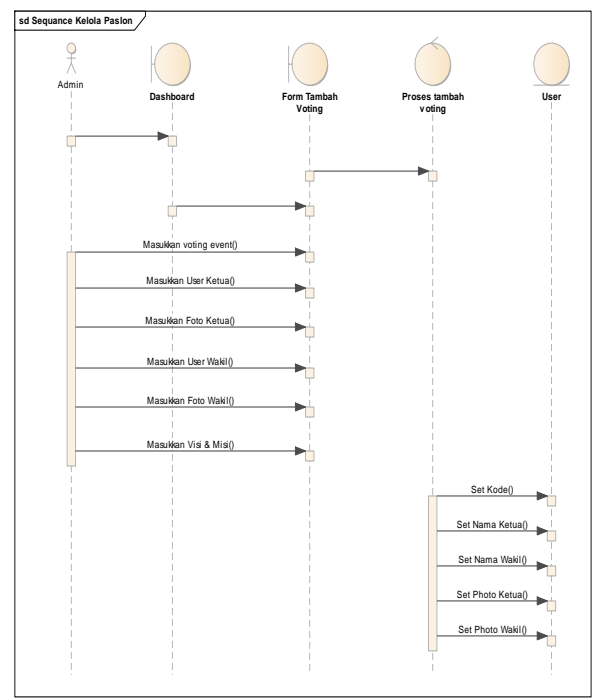

Gambar 5 Sequence Diagram Tambah User b. Sequence Diagram Kelola Paslon

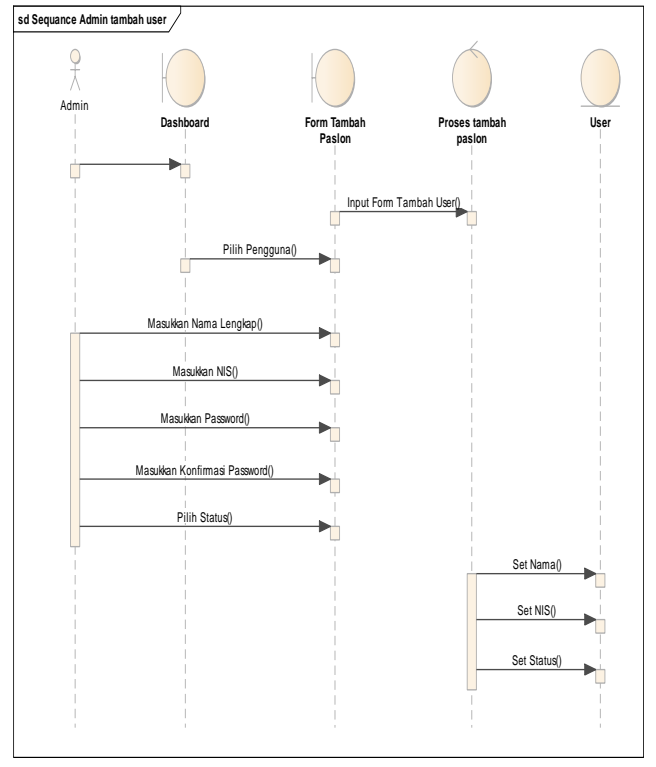

Gambar 6 Sequence Diagram Kelola Paslon

4. Database

a.

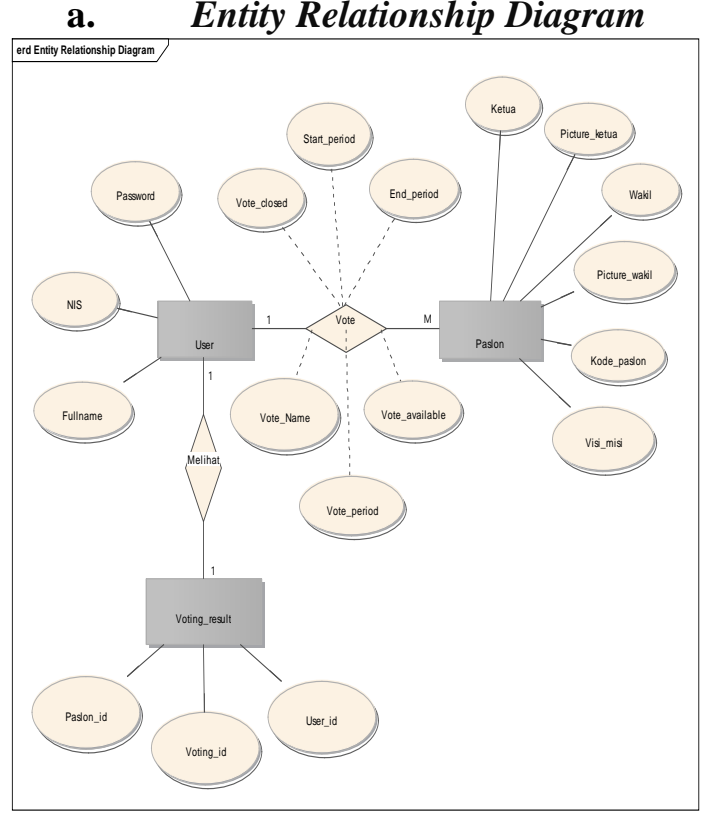

Gambar 7 Entity Relationship Diagram Evoting OSIS SMK Perguruan Cikini 
b. Logical Relation Structure

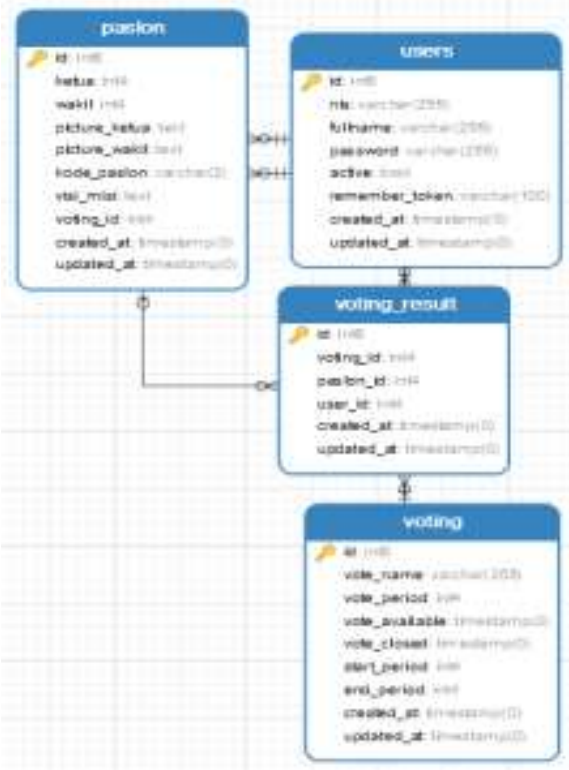

Gambar 8 Logical Record Structurre E-Voting OSIS SMK Perguruan Cikini

5. Interface

a. Tampilan Halaman Login

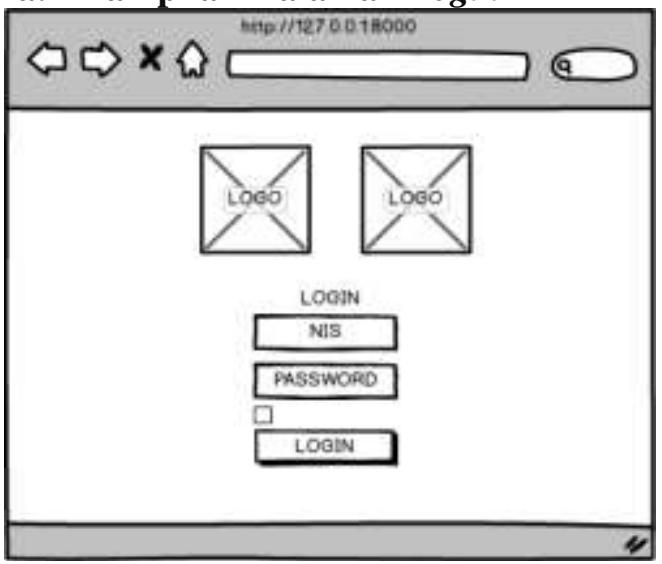

Gambar 9 Tampilan Halaman Login b. Tampilan Dashboard Admin

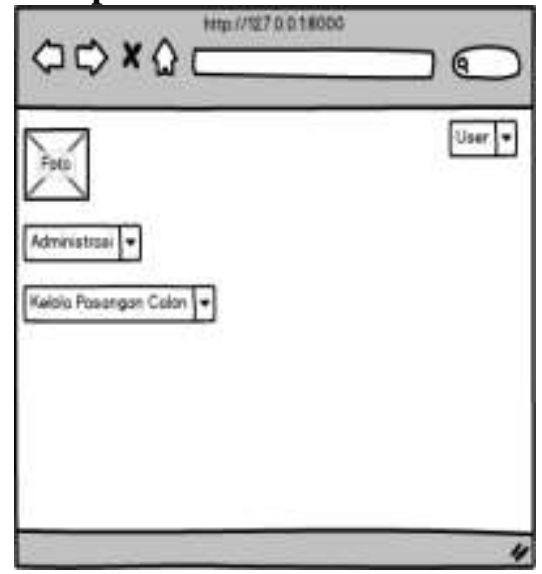

Gambar 10 Tampilan Dashboard Admin

c. Tampilan Dashboard Siswa

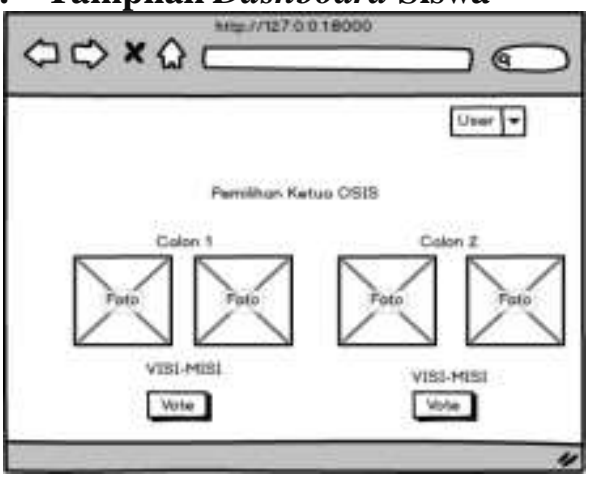

Gambar 11 Tampilan Dashboard Siswa

d. Tampilan Vote Result

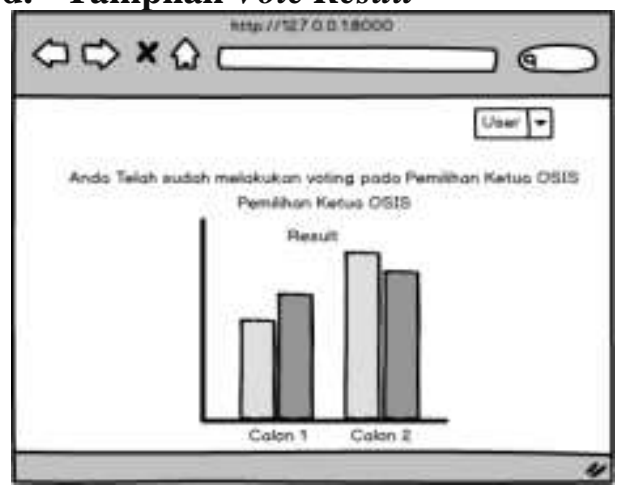

Gambar 12 Tampilan Vote Result 


\section{KESIMPULAN}

Berdasarkan uraian yang telah dibahas sebelumnya, beberapa kesimpulan mengenai perancangan website E-voting pemilihan Ketua OSIS SMK Perguruan Cikini:

- Dengan adanya sistem e-voting ini diharapkan dapat membantu pihak OSIS (Organisasi Siswa Intra Sekolah) dalam menjalankan pemilihan Ketua baru.

- Dengan adanya sistem $e$-voting ini kita tidak perlu menggunakan media kertas sebagai surat suara.

- Dengan sistem ini para siswa dapat lebih mudah ikut serta dalam kegiatan voting tanpa mengganggu jam belajar mereka.

\section{REFERENSI}

Choer Yusfar Ilhaqul, K. D. (n.d.). No Title. Jurnal Algoritma, 17-24.

Lestanti, S., \& Susana, A. D. (2016). Jurnal Antivirus, Vol. 10, 10(2), 69-77.

Permana, A. A. (2016). Rancangan Sistem Informasi Simpan Pinjam Pada Koperasi Guru dan Pegawai SMP Negeri 45 Jakarta. JIKA (Jurnal Informatika) Vol. 1 No.2 2017 ISSN 2549 - 0710.

Ridwan, M., \& Arifin, Z. (2016). Rancang Bangun E-Voting dengan menggunakan Keamanan Algoritma Rivest Shamir Adleman (RSA) Berbasis WEB (Studi Kasus: Pemilihan Ketua BEM FMIPA), 11(2), 22-28.

Sasmito, G. W. (2017). Penerapan Metode Waterfall Pada Desain Sistem Informasi Geografis Industri Kabupaten Tegal, 2(1), 6-12.

Wira, D., Putra, T., \& Andriani, R. (2019). Unified Modelling Language (UML) dalam Perancangan Sistem Informasi Permohonan Pembayaran Restitusi SPPD, 7(1).

Zaen Mohammad Tufan Asri, P. R. (2018). Aplikasi Voting Pemilihan Ketua Organisasi Siswa Intra Sekolah (OSIS) pada MA Nurul Ihsan NW Tilawah Berbasis WEB, 1(2), 4348. 